DOI:10.17951/h.2015.59.2.233

\begin{tabular}{lcc}
\hline & A N N A L E S \\
UNIVERSITATIS MARIAE CURIE-SKŁODOWSKA & LUBLIN - POLONIA \\
VOL. XLIX, 2 & SECTIOH H \\
\hline
\end{tabular}

Uniwersytet Marii Curie-Skłodowskiej w Lublinie, Katedra Bankowości

JERZY WĘCŁAWSKI

e-mail: jerzy.weclawski@poczta.umcs.lublin.pl

\title{
Unia bankowa jako element europejskiej sieci bezpieczeństwa finansowego
}

The Banking Union as a component of financial security net

\begin{abstract}
Słowa kluczowe: stabilność finansowa, instytucje finansowe ważne systemowo, nadzór bankowy, unia bankowa
\end{abstract}

Keywords: financial stability, Systemically Important Financial Institutions, bank supervision, Banking Union

\section{Wstęp}

Na przestrzeni ostatnich kilkudziesięciu lat doszło do istotnego zwiększenia znaczenia sektora finansowego w gospodarce. W szeregu krajów wysoko rozwiniętych sfera finansowa przekroczyła swoimi rozmiarami sferę realną gospodarki. Dominacja tak wynikała przy tym w coraz większej mierze z przeprowadzania operacji finansowych oderwanych od procesów produkcji i świadczenia usług. Konkurencja pomiędzy instytucjami finansowymi skłaniała je do stałego wzrostu w drodze fuzji i przejęć innych podmiotów. Doprowadziło to do powstania pośredników finansowych, w szczególności banków, których ewentualna upadłość stwarzała zagrożenie destabilizacją całych gospodarek. Potwierdzeniem tych obaw stał się rozwój sytuacji w trakcie kryzysu finansowego, który rozpoczął się w 2008 r. za sprawą banków zaangażowanych w nadmiernie ryzykowne operacje na rynku kredytów hipotecznych. Rozprzestrzenienie się tego kryzysu na sferę realną, a następnie doprowadzenie do kryzysu finansów publicznych, spowodowało z jednej strony zmianę nastawienia do dużych banków, a $\mathrm{z}$ drugiej skłoniło do wprowadzania regulacji mających zapobiec przenoszeniu ryzyka ich działalności na podatników. 
Kryzys z lat 2008-2010 przyspieszył w ramach Unii Europejskiej działania zmierzające do integracji transgranicznej i zwiększenia nadzoru nad bankami. Prace nad stworzeniem służącej do tego unii bankowej znajdują się w odniesieniu do poszczególnych jej elementów na różnym etapie realizacji. Celem opracowania jest określenie przyczyn utworzenia unii bankowej i krytyczna analiza mechanizmów nadzoru nad bankami ważnymi systemowo. Mechanizmy unii bankowej są dopiero wdrażane, dlatego na tym etapie nie jest jeszcze możliwa ocena ich skuteczności. W pracy zastosowano następujące metody badawcze - metodę dedukcji oraz analizy danych zastanych w badanym zakresie. Ze względu na dynamikę badanych zjawisk i procesów w niniejszym opracowaniu uwzględniono stan prawny na koniec sierpnia $2014 \mathrm{r}$.

\section{Banki ważne systemowo i zagrożenia $z$ nimi związane}

Postępująca w ostatnich dwóch dekadach XX wieku deregulacja i liberalizacja sektora finansowego doprowadziła do coraz większej finansyzacji gospodarek. Zjawisko to polega na znaczącym wzroście roli sektora finansowego w gospodarce i finansowych motywów prowadzenia działalności gospodarczej. Przejawami finansyzacji jest znaczący wzrost obrotów na rynkach finansowych, wzrost zadłużenia podmiotów prywatnych i publicznych, wprowadzanie do obrotu ogromnej liczby nowych instrumentów finansowych, włączanie do sfery finansowej rynków i podmiotów ze sfery realnej, autonomizacja sektora finansowego wynikająca z oderwania zmian cen aktywów finansowych od czynników fundamentalnych [Małecki, 2014, s. 468].

Banki, jako jedna $\mathrm{z}$ instytucji tworzących system finansowy, odgrywają różną rolę w poszczególnych krajach. W krajach należących do strefy euro, których $\mathrm{w}$ decydującej mierze dotyczą rozważania prowadzone w tym artykule, systemy finansowe są zorientowane bankowo. Aktywa systemu finansowego w tych krajach w relacji do PKB stanowiły w 2012 r. 502,2\%, a aktywa samych banków 344,6\% PKB [Rozwój, 2012, s. 11, 13].

W krajach Unii Europejskiej działa ok. 8000 banków, w tym 6000 w strefie euro [Banking, 2013, s. 6]. Ich liczba na przestrzeni ostatnich kilku dziesięcioleci szybko malała w wyniku fuzji i przejęć. Procesy te doprowadziły do powstania dużych banków w formie konglomeratów finansowych i holdingów świadczących usługi bankowości komercyjnej, inwestycyjnej, ale także ubezpieczeniowe, factoringowe, leasingowe, zarządzania aktywami i szereg innych. Przedsiębiorstwa te osiągają ogromne rozmiary, o czym świadczy np. ich wyposażenie w kapitał własny (stan na koniec 2012 r. w mld USD): HSBC - 151, BNP Paribas - 99, RBS - 88, Credit Agricole - 81, Banco Santander - 81, Barclays - 80, Lloyds Banking Group - 67, Deutsche Bank - 66, UniCredit - 64, Groupe BPCE - 61 [Top 1000, 2013]. Funkcjonowanie na rynku tak dużych podmiotów prowadzi do silnego uzależnienia stabilności gospodarek od ich sytuacji finansowej. Na koniec 2011 r. aktywa 10 największych banków w Unii Europejskiej stanowiły 122\% unijnego PKB [European, 
2013, s. 19]. Relacja aktywów największego w danym kraju banku do jego PKB osiągnęła $\mathrm{w}$ wielu krajach imponujące rozmiary - przykładowo aktywa ING wynosiły 162\% PKB Holandii, aktywa HSBC 120\%, PKB W. Brytanii, a aktywa BNP Paribas 100\% PKB Francji [Top 1000, 2013; Eurostat]. Aktywa banków w dużym zakresie nie powstają przy tym w wyniku finansowania klientów, lecz prowadzenia operacji na własny rachunek. Można zatem stwierdzić, że podmioty te oderwały się od swoich fundamentów i tworzą w dużym stopniu byt sam w sobie.

Przez szereg lat uzasadniano potrzebę koncentracji w sektorze bankowym i konieczność tworzenia dużych banków z możliwością osiągania w ich działalności efektów skali oraz zapotrzebowania na finansowanie ze strony dużych korporacji. Badania empiryczne prowadzone w tym zakresie wskazują jednak, że argumenty te nie znajdują potwierdzenia. Efekty skali stają się ograniczone po przekroczeniu pewnej wielkości instytucji finansowej, a korporacje nie koncentrują swojego finansowania w jednym podmiocie i stosują alternatywne do kredytów bankowych sposoby pozyskiwania środków finansowych [Małecki, 2014, s. 471]. Osiągnięcie znaczącej pozycji przez duże banki znalazło swoje odzwierciedlenie w określeniu ich mianem instytucji finansowych ważnych systemowo (Systemically Important Financial Institutions, SIFI). Ze względu na ich wpływ na gospodarkę od wielu lat stosowano w odniesieniu do nich doktrynę: ,zbyt duży, aby upaść” [Völz, Vedow, 2011, s. 195]. Następstwem istnienia dużych instytucji finansowych są zagrożenia dla stabilności rynków finansowych i gospodarek realnych w przypadku upadłości takich podmiotów. W okresie ostatniego kryzysu finansowego banki centralne i rządy robiły wszystko, aby przezwyciężyć ich problemy finansowe i nie dopuścić do upadłości.

Ratowanie dużych banków przed upadłością następowało przez ich dokapitalizowanie na ogromną skalę ze środków publicznych. Duże banki potrafiły szybko wyjść z kryzysu i wiele z nich spłaciło zadłużenie wobec państw i wyzwoliło się spod ich kurateli. Kryzys finansowy nie zmienił przy tym ani kultury, ani mentalności sektora bankowego i transakcje banków nie stały się bardziej przejrzyste niż przed kryzysem [Global, 2012, s. 125]. Nastąpił jednak przełom w polityce bezpieczeństwa finansowego ze strony państwa. Rozwiązania problemu dużych banków idą w dwóch kierunkach. Po pierwsze, podejmuje się działania administracyjne ograniczające rozmiary pojedynczej instytucji finansowej i zakazujące łączenia określonych rodzajów działalności w ramach jednego podmiotu. Po drugie, zwiększa się wymogi kapitałowe w stosunku do dużych banków, poddaje je wspólnotowemu nadzorowi i wprowadza mechanizmy restrukturyzacji i uporządkowanej likwidacji.

\section{Wzmacnianie regulacji sektora bankowego}

W ostatnich kilku dziesięcioleciach obserwowane jest poszerzanie zakresu regulacji działalności banków i nadzoru nad nimi. Kryzys finansowy z 2008 r. i odpowiedzialność wielkich banków za jego wywołanie przyspieszyły te procesy. Komisja 
Europejska powierzyła przygotowanie zaleceń odnośnie do reformy sektora bankowego grupie roboczej kierowanej przez Erkkiego Liikanena, która sformułowała dość radykalne postulaty [High-level, 2012, s. 99-109]. Zaproponowała ona rozdzielenie w największych bankach działalności na rzecz klientów indywidualnych i korporacyjnych, w tym obrotu instrumentami finansowymi. Chociaż propozycje te nie zostały w pełni zaakceptowane, to stworzyły punkt wyjścia do przebudowy architektury nadzoru bankowego.

Tworzenie nowego systemu bezpieczeństwa finansowego w Unii Europejskiej, obejmuje zarówno powstanie nowych instytucji, jak i wprowadzenie nowych norm nadzorczych. Można wskazać kilka kierunków zmian w tym zakresie. Po pierwsze, dotychczas stosowany nadzór mikroostrożnościowy uzupełnia się nadzorem makroostrożnościowym. Po drugie, wymaga się lepszego wyposażenia banków w kapitały własne. Po trzecie, zwiększa się zakres nadzoru transgranicznego. Po czwarte, zmierza się do przeniesienia odpowiedzialności za stabilność dużych banków z władz publicznych na ich właścicieli i wierzycieli oraz sektor bankowy. Rozwiązania te są aktualnie wdrażane i o ich skuteczności będzie można wypowiadać się dopiero za kilka lat. Zmierzają one jednak niewątpliwie do stopniowego wyzwolenia się władz publicznych od ciężaru ratowania dużych banków przed upadłością.

Zmiany w systemie nadzoru nad bankami w Unii Europejskiej zostały zapoczątkowane pod koniec $2010 \mathrm{r}$. [Regulation 2010]. Stanowiły one kompromis pomiędzy zwolennikami wprowadzenia jednolitego nadzoru a zachowania status quo. Doświadczenie kryzysu finansowego wskazało na niedostateczny nadzór nad ryzykami makroekonomicznymi, co skłoniło do powołania w grudniu 2010 r. Europejskiej Rady Ryzyka Systemowego wykonującej nadzór makroostrożnościowy nad systemem finansowym na obszarze całej Unii. Na szczeblach krajowych powstały jego odpowiedniki skupiające przedstawicieli ministerstw finansów, banków centralnych, nadzorów bankowych. Ich zadaniem jest formułowanie ostrzeżeń i zaleceń dotyczących czynników ryzyka systemowego kierowanych pod adresem rządów i regulatorów krajowych [Boegl, 2013/6, s. 17]. Konstatując z kolei fakt, że duże banki działają ponadnarodowo, a nadzór nad nimi wykonywany jest przez organy kraju pochodzenia, w styczniu 2011 r. powołano do życia trzy instytucje sektorowe nadzorujące główne segmenty rynku finansowego: Europejski Urząd Nadzoru Bankowego z siedzibą w Londynie, Europejski Urząd Nadzoru Giełd i Papierów Wartościowych z siedzibą w Paryżu oraz Europejski Urząd Nadzoru Ubezpieczeń i Pracowniczych Programów Emerytalnych z siedzibą we Frankfurcie. Zadaniem tych urzędów, tworzących Europejski System Organów Nadzoru Finansowego, jest koordynacja działań nadzoru mikroostrożnościowego wykonywanego przez nadzorców krajowych [Mitręga-Niestrój, 2011, s. 37].

Wprowadzenie nowych wymogów kapitałowych dla banków jest rezultatem uzgodnienia w ramach Bazylejskiego Komitetu Nadzoru Bankowego modyfikacji i uzupełnień umowy kapitałowej (Bazylea III). Są one wprowadzane w Unii Europejskiej w ramach Pakietu CRD IV/CRR [Regulation 2013; Directive 2013]. 
Zmianą $\mathrm{w}$ zasadach stanowienia prawa $\mathrm{w}$ zakresie nadzoru bankowego jest przy tym przyjęcie tego dokumentu w formie dyrektywy, wymagającej implementacji do prawa krajowego, oraz rozporządzenia obowiązującego bezpośrednio we wszystkich krajach. Jego uzupełnieniem są standardy techniczne wydane przez Europejski Urząd Nadzoru Bankowego. Łącznie do Pakietu CRD IV/CRR wydanych będzie około 100 aktów wykonawczych. Pakiet CRD IV/CRR zwiększa wymogi kapitałowe, a zwłaszcza wymagania odnośnie do wyposażenia banków w najbardziej stabilne elementy funduszy podstawowych (Trier 1) i uzupełniających (Trier 2), wprowadza pięć nowych buforów kapitałowych, w tym możliwość nałożenia specjalnego wymogu na ważne systemowo instytucje finansowe. Oznacza to, że od dużych banków od 2019 r., gdy ostatecznie wejdą w życie wszystkie wymienione regulacje, możliwe będzie wymaganie dysponowania kapitałem własnym w wysokości $15,5 \%$ pozycji ważonych ryzykiem [Ortgies, 2013, s. 20].

Jednocześnie przystąpiono do tworzenia unii bankowej obejmującej kilka mechanizmów nakierowanych na stabilność sektora bankowego:

- jednolity mechanizm nadzorczy (Single Supervisory Mechanizm, SSM),

- jednolity mechanizm restrukturyzacji i uporządkowanej likwidacji (Single Resolution Mechanizm, SRM),

- jednolity system gwarantowania depozytów (Single Deposit Guarantee Scheme, SDGS).

Według stanu prac na połowę 2014 r. wiadomo, że unia bankowa rozpocznie działalność w niepełnym kształcie. Najwcześniej zacznie funkcjonować SSM (4 listopada 2014 r.), a następnie SRM (1 stycznia 2015 r.). Natomiast na razie zrezygnowano $\mathrm{z}$ budowy jednolitego systemu gwarantowania depozytów. Różnice pomiędzy systemami w poszczególnych krajach członkowskich Unii są na tyle duże, że zdecydowano się jedynie na zwiększenie stopnia harmonizacji systemów krajowych przez przyjęcie nowelizacji dyrektywy dotyczącej gwarantowania depozytów bankowych [Directive, 2014/49].

\section{Instytucje i procedury jednolitego nadzoru bankowego}

Jednolitym nadzorem zostają objęte obligatoryjnie instytucje ważne systemowo w krajach strefy euro oraz w krajach, które dobrowolnie przystąpią do unii bankowej. Do takich instytucji zaliczono banki, które:

- dysponują aktywami o wartości przekraczającej 30 mld euro lub

- posiadają aktywa przekraczające $20 \%$ PKB ich kraju macierzystego i większe niż 5 mld euro, lub

- zostaną uznane za ważne systemowo przez EBC na wniosek krajowego organu nadzoru oraz

- korzystały z pomocy Europejskiego Mechanizmu Stabilności (European Stability Mechanism) [Council, 2013]. 
Niezależnie od banków zaliczonych na podstawie powyższych kryteriów do grupy SIFI jednolity nadzór obejmie trzy najbardziej znaczące banki w każdym kraju. Przewiduje się, że pod jednolity nadzór będzie podlegało około 150 banków skupiających $80 \%$ aktywów bankowych strefy euro [Unia, 2013, s. 18]. Pozostałe banki w danym kraju będą nadal objęte nadzorem krajowym. Jednak w przypadku zagrożenia stabilności finansowej, w celu zapewnienia przestrzegania odpowiednich standardów, ECB może rozciągnąć swój bezpośredni nadzór także na inne banki [Röseler, 2014, s. 8].

Dla prowadzenia jednolitego nadzoru nie można było powołać nowej instytucji bez zmiany traktatu z Maastricht. Dlatego zdecydowano się, że nadzór będzie sprawowany przez Radę Nadzoru (Supervisory Bard) umiejscowioną w strukturach ECB, przy współpracy z krajowymi organami nadzoru. Rada składa się z przedstawicieli ECB, organów nadzoru krajów członkowskich strefy euro oraz krajów spoza strefy, które przystąpią do unii bankowej. Proces decyzyjny polega na przygotowywaniu i przedkładaniu przez Radę Nadzoru projektów decyzji Radzie Prezesów EBC (Governing Council). Jeżeli w przeciągu 10 dni roboczych nie zgłosi ona sprzeciwu, to decyzję uznaje się za podjętą. Oznacza to, że formalnie decyzje są podejmowane przez Radę Prezesów.

Jednolity nadzór bankowy jest nadzorem mikroostrożnościowym. Do wyłącznych kompetencji ECB, niezależnie od tego, czy bank został uznany za istotny systemowo, przekazano: wydawanie i cofanie licencji, wydawanie zgody na tworzenie oddziałów i podejmowanie działalności transgranicznej w krajach nienależących do unii bankowej, oceny transakcji nabycia bądź zbycia kwalifikowanych pakietów akcji. Poza tym do kompetencji ECB należy w odniesieniu do banków poddanych jego bezpośredniemu nadzorowi kontrola przestrzegania wymogów adekwatności kapitałowej, dźwigni finansowej i płynności, realizacji programów naprawczych, przeprowadzanie stress testów, wdrażanie środków wczesnej interwencji, gdy bank nie spełnia wymogów regulacyjnych. ECB posiada także uprawnienia do żądania dostępu do informacji, przeprowadzania inspekcji na miejscu oraz nakładania administracyjnych sankcji finansowych [Żabińska, 2014, s. 86].

Kraje nienależące do strefy euro mogą dobrowolnie uczestniczyć w jednolitym nadzorze poprzez nawiązanie „bliskiej współpracy” z ECB. Warunkami nawiązania takiej współpracy jest m.in. dostosowanie przepisów prawa krajowego do wymogów nadzoru prowadzonego przez ECB, zagwarantowanie stosowania przez krajowy organ nadzoru wytycznych ECB, przekazywanie ECB informacji niezbędnych do wykonywania nadzoru nad bankami. Kraje spoza strefy euro, przystępując do unii bankowej, mają zapewniony udział ich przedstawiciela w Radzie Nadzoru, ale nie będąc reprezentowanym w Radzie Prezesów, nie mają wpływu na ostateczne decyzje podejmowane przez nadzór. Uczestnicząc w jednolitym nadzorze, nawet jako kraj stowarzyszony, mają one możliwość pewnego wpływu na postępowanie banków zagranicznych [Hryckiewicz, Pawłowska, 2014, s. 540]. W przypadku niezadowolenia z decyzji dotyczących ich banków krajom stowarzyszonym stworzono możliwość wystąpienia z SSM. 


\section{Zasady restrukturyzacji i uporządkowanej likwidacji dużych banków}

Stosowana dotychczas polityka krajowych władz nadzorczych ochrony dużych banków przed upadłością determinowana była dążeniem do wspierania narodowych instytucji finansowych oraz obawą przed konsekwencjami ich upadku dla lokalnego rynku bankowego. Dlatego dopuszczenie możliwości ogłaszania upadłości dużych banków musiało być powiązane z przeniesieniem decyzji w tym zakresie ze szczebla narodowego na unijny. Jednocześnie jednak dla ochrony stabilności rynku celowe było zastosowanie w odniesieniu do banków przeżywających problemy finansowe rozwiązań o charakterze etapowym: dokapitalizowania instytucji możliwych do uratowania, restrukturyzacji podmiotów mających poważniejsze problemy, a dopiero w ostateczności likwidacja tych, w których skala strat jest zbyt duża dla ich ochrony przed upadłością. Realizacji zadań w tym zakresie służy drugi element unii bankowej, którym jest jednolity mechanizm restrukturyzacji i uporządkowanej likwidacji (SRM) oraz związany z nim jednolity fundusz naprawczy (Single Resolution Fund, SFR) służący do ich dokapitalizowania. Mechanizm restrukturyzacji i uporządkowanej likwidacji ma zastosowanie tylko do instytucji kredytowych ważnych systemowo. SRM został wprowadzony rozporządzeniem Parlamentu Europejskiego i Rady Unii Europejskiej i obejmuje banki mające siedzibę w krajach strefy euro, a kraje spoza niej będą mogą do niego przystąpić na zasadzie dobrowolności [Regulation, 2014]. Oprócz tego w maju 2014 r. przyjęta została dyrektywa Parlamentu Europejskiego i Rady Unii Europejskiej w sprawie restrukturyzacji i uporządkowanej likwidacji, której postanowienia muszą zostać przeniesione do systemów prawnych wszystkich krajów członkowskich Unii Europejskiej [Directive, 2014/59]. Wprowadzono w ten sposób jednolite standardy dla realizacji zadań nadzorczych w tym zakresie we wszystkich krajach unijnych.

Przepisy dotyczące restrukturyzacji i uporządkowanej likwidacji banków wprowadzają system określany jako bail-in. Przewiduje on, że od 2016 r. straty banków do wysokości $8 \%$ aktywów pokrywać będą w pierwszej kolejności akcjonariusze, posiadacze obligacji, a w dalszej przez posiadaczy depozytów powyżej 100000 euro. Dopiero po przekroczeniu tych progów angażowane będą środki pomocowe z SRM i ESM. Rozwiązanie takie ma zwiększyć presję na zarządy banków, aby nie podejmowały zbyt dużego ryzyka.

Funkcjonowanie SRM opiera się na silnie rozbudowanych rozwiązaniach instytucjonalnych i procedurach decyzyjnych. Kluczowym gremium jest Rada ds. Restrukturyzacji i Uporządkowanej Likwidacji (Single Resolution Board, SRB). Będzie się ona składała z dyrektora wykonawczego i czterech stałych członków. W przypadku rozpatrywania przez Radę sprawy dotyczącej danego kraju jej członkiem staje się przedstawiciel krajowego organu restrukturyzacji i uporządkowanej likwidacji. Natomiast ECB i Komisja Europejska powołują do Rady przedstawicieli w charakterze obserwatorów. Podstawowym zadaniem Rady jest przygotowywanie planów restrukturyzacji i uporządkowanej likwidacji banków. W ciągu 24 godzin od 
przyjęcia przez Radę planu restrukturyzacji i uporządkowanej likwidacji Komisja Europejska może plan zaakceptować bądź zgłosić do niego zmiany. Wprowadzenie zmian przez Komisję zobowiązuje RSB do ich uwzględnienia. Rozwiązanie takie oznacza ograniczenie autonomii neutralnego gremium decyzyjnego przez ingerencję czynnika politycznego przy podejmowaniu decyzji o likwidacji banku [Goedeckemeyer, 2014, s. 9]. Rozporządzenie chroni w niezbędnym zakresie interesy państw członkowskich, które przystąpią na zasadzie dobrowolności do SRM, jak i państw pozostających poza nim. Interesy państw przystępujących do mechanizmu są chronione przez włączenie ich przedstawicieli do gremiów decyzyjnych. Natomiast pozycja państw pozostających poza mechanizmem jest chroniona przez zakaz dyskryminacji instytucji kredytowych ze względu na kraj pochodzenia.

Dla przeprowadzania działań naprawczych wykorzystywane będą środki z SFR, tworzonego ze składek wnoszonych przez banki. Fundusz będzie tworzony od początku 2016 r. i w ciągu 8 lat ma osiągnąć poziom co najmniej 1\% wartości depozytów gwarantowanych wszystkich państw członkowskich objętych SRM, tj. 55 mld euro. W pierwszym roku funkcjonowania funduszu $40 \%$ jego środków będzie stanowiło część wspólną, a pozostałe będą podzielone na części odpowiadające wielkości składek wniesionych przez poszczególne kraje. W kolejnych latach wspólna pula będzie powiększana [Directive, 2014]. Po zakończeniu tworzenia funduszu nie będzie możliwe udzielanie pomocy finansowej ani ze środków krajowych, ani z mechanizmu wsparcia kapitałowego ESM. Przewiduje się, że w sytuacji, gdyby kapitał w wysokości 55 mld euro był zbyt mały dla ratowania banków, SFR będzie finansował się poprzez rynek. Rządy przestaną tym samym pełnić rolę ostatecznego gwaranta bezpieczeństwa sektora bankowego.

\section{Problem rozdzielenia działalności bankowej}

Ostatnim elementem zmian odnoszących się do dużych banków są rozwiązania dotyczące rozdzielenia transakcji wykonywanych z użyciem własnych środków od klasycznej działalności depozytowo-kredytowej. W styczniu 2014 r. został ogłoszony projekt rozporządzenia Parlamentu Europejskiego i Rady w sprawie środków strukturalnych mających zwiększyć odporność instytucji kredytowych w Unii Europejskiej na szoki kryzysowe. Dotyczy on największych banków zaliczonych do grupy too big too fail, ale jednocześnie zbyt kosztownych, żeby je ratować i zbyt skomplikowanych, żeby je w uporządkowany sposób likwidować [Proposal, 2014]. Proponowane regulacje nawiązują do postulatów zgłoszonych w raporcie Liikanena. Rozporządzenie przewiduje zakaz handlu przez banki na własny rachunek instrumentami finansowymi i surowcami oraz możliwość żądania przez nadzór przeniesienia niektórych ryzykownych rodzajów działalności handlowej do odrębnych podmiotów. Natomiast pozostałe operacje finansowe, realizowane na zlecenie klientów, ale związane $\mathrm{z}$ wysokim ryzykiem, jak np.: handel złożonymi instrumentami pochodnymi, 
sekurytyzacja i operacje market making, będą dozwolone, ale poddane nadzorowi bankowemu. W razie stwierdzenia zbyt wysokiego ich ryzyka nadzór będzie mógł nakazać wydzielenie ich do osobnej spółki. Tego typu ograniczenia działalności będą dotyczyły banków, których aktywa przekroczą 70 mld euro, a działalność objęta regulacjami 30 mld euro lub 10\% łącznych aktywów. Aktualnie do tej grupy zalicza się w Unii Europejskiej 30 instytucji kredytowych [Top 1000, 2013].

\section{Ocena nowego systemu bezpieczeństwa banków}

Nowe rozwiązania w zakresie nadzoru nad bankami wprowadzane w formie unii bankowej nie są regulacją kompleksową. Zostały one przygotowane jako reakcja na zagrożenia wynikające $\mathrm{z}$ funkcjonowania dużych banków i to one znajdą się pod bezpośrednim nadzorem EBC. Nie dokonano natomiast zmian czy likwidacji dotychczas funkcjonujących nadzorów. Zmiana podejścia do instytucji ważnych systemowo była potrzebna, gdyż ich rozmiary i prowadzona polityka zaczęły zagrażać nie tylko stabilności rynków finansowych, ale także stały się niekorzystne z punktu widzenia utrzymywania konkurencji. Można spotkać się z poglądem, że banki o aktywach przekraczających $100 \%$ PKB danego kraju mają negatywny wpływ na wzrost gospodarczy [Armand, 2012, s. 23]. Nie oznacza to, że celowy jest podział tych banków z punktu widzenia rodzajów działalności. System oparty na bankach uniwersalnych może być tak samo stabilny, jak system rozdzielający bankowość komercyjną i inwestycyjną. Nie należy zatem administracyjnie ingerować w modele działalności banków, lecz wymagać od nich wyposażenia w odpowiednie kapitały i przejrzystych struktur [Jordan, 2013, s. 21].

Kolejnym problemem współczesnych gospodarek jest oderwanie się banków od sfery realnej. Prowadzenie przez nie na znaczną skalę handlu na rynkach finansowych dla własnego zysku, z której klienci nie mają żadnego pożytku, a są jedynie narażeni na ryzyko upadłości banku, powinno być zdecydowanie ograniczone. Propozycje rozwiązań w tym zakresie zostały sformułowane, ale ich wdrożenie odkładane jest w czasie. Unia Europejska jest w tym zakresie mniej zdecydowana w porównaniu do Stanów Zjednoczonych, które przyjęły takie regulacje.

Kryzys finansowy wskazał, że dotychczasowy system narodowego nadzoru nad bankami i podejmowanie politycznych decyzji o ich ratowaniu ze środków publicznych nie przystaje do warunków współczesnej gospodarki. Postępująca koncentracja banków powoduje, że zasoby finansowe poszczególnych krajów przestają wystarczać na ochronę narodowych instytucji finansowych. Polityka ochrony własnych banków narusza przy tym zasady wolnego rynku i wolnej konkurencji, leżące u podstaw funkcjonowania Unii Europejskiej. Jako zasadne należy uznać wprowadzane w ramach unii bankowej podejście polegające na tym, że im większy bank, a tym samym większe zagrożenie dla stabilności rynku, tym bardziej restrykcyjnym regulacjom powinien podlegać. 
Unia bankowa nie zabezpieczy w pełni rynku przed ryzykiem wystąpienia kryzysu. Jest jednak niewątpliwie przedsięwzięciem zmierzającym do zapewnienia większego bezpieczeństwa i stabilności sektora bankowego. Zmienia ona w stosunku do dużych banków nadzorcę krajowego na podmiot ponadnarodowy. Nadzór ponadnarodowy znacznie ograniczy władztwo organów krajowych i zjawisko regulatory capture przejawiające się w niedostatecznym wykonywaniu zadań wobec krajowych banków, a nawet podporządkowywania się ich interesom. EBC w roli nadzorcy będzie się kierował bezpieczeństwem Unii Europejskiej, a nie interesami kraju, z którego dany bank pochodzi. Pozwoli to na przerwanie błędnego koła powiązań między dużymi bankami a rządami ich macierzystych krajów. Działania te są jednak realizowane bardziej pod wpływem presji wydarzeń na rynku finansowym niż w wyniku dążenia do pogłębienia integracji gospodarczej. Ich konstrukcja jest wynikiem ścierania się różnych interesów, a nie przyjęcia spójnej koncepcji. Dlatego też są niekompletne i budzą określone wątpliwości co do swojej skuteczności. Sprzeczność interesów poszczególnych państw członkowskich Unii Europejskiej sprawia, że mechanizmy te wprowadzane są etapowo i nie obejmują wszystkich krajów.

Podjęte w skali ponadnarodowej przedsięwzięcia zmierzające do wzmocnienia kapitałów banków (Bazylea III) zwiększą stabilność rynków finansowych. Dotyczą one w szczególności dużych banków, dla których organa nadzoru będą mogły nakładać dodatkowe wymogi kapitałowe (bufor kapitałowy 1\%-2,5\%). Zmiany te będą jednak miały silny wpływ na modele działalności bankowej. Można się obawiać, że banki mające problemy ze zgromadzeniem odpowiedniej wielkości kapitału własnego będą ograniczały działalność depozytowo-kredytową na rzecz operacji na rynku kapitałowym. Może to prowadzić do ograniczenia dostępności do kredytów i podniesienia ich kosztów [Meller, 2013, s. 99].

Obecna fala regulacyjna prowadzi do powstania wielu instytucji i ogromnej liczby przepisów wykonawczych związanych z nadzorem nad bankami. Grozi to przeregulowaniem systemu, a w efekcie niską jego skutecznością. Zwiększa się ryzyko prawne związane z jego funkcjonowaniem. Banki będą wzmacniać procedury zapewnienia zgodności z regulacjami zamiast doskonalić procedury zarządzania ryzykiem. Powstaje także pytanie o zachowanie optymalnych proporcji pomiędzy regulacją a swobodą konkurencji na rynku bankowym. Prawodawcom trudno jest ująć w przepisach skomplikowaną strukturę rynków finansowych. Stwarza to ryzyko manipulowania przez banki klasyfikacjami transakcji w celu obchodzenia restrykcji regulacyjnych. $Z$ kolei kontrola ich przestrzegania przez banki związana jest ze wzrostem kosztów działalności regulatorów.

Jednolitym nadzorem oraz mechanizmem restrukturyzacji i uporządkowanej likwidacji zostają objęte instytucje uznane za ważne systemowo. Kryteria zaliczenia do tych instytucji mają charakter arbitralny, gdyż wynikają z przyjęcia określonych wskaźników kwotowych bądź oceny znaczenia banku dla danego kraju [Boegl, 2013/9, s. 21]. Pozostałe banki będą nadal nadzorowane przez krajowe organy. Oznacza to, że wszystkie istotne decyzje o ich działalności operacyjnej, restrukturyzacji 
i likwidacji będą zapadały z uwzględnieniem interesów narodowych. Jednolitym nadzorem nie będą objęte banki spoza Unii Europejskiej, co też stwarza możliwość stosowania arbitrażu regulacyjnego.

Wprowadzenie unii bankowej jest z jednej strony wyrazem determinacji do pogłębiania integracji gospodarczej, ale z drugiej oznacza dopuszczenie podziałów wewnątrz Unii Europejskiej na trzy grupy: kraje, które przyjęły wspólną walutę, obligatoryjnie wchodzą do unii bankowej, kraje, które dobrowolnie przystąpią do unii bankowej, oraz kraje, które pozostaną poza nią. Kraje dobrowolnie przystępujące do unii bankowej nie będą dysponowały pełnią praw przysługujących członkom strefy euro. Przewidziana jest także możliwość ich wystąpienia z unii bankowej, co może być czynnikiem dezintegrującym całe ugrupowanie. Rozwiązania takie oznaczają segmentację rynku finansowego i nie sprzyjają jego stabilności.

W unii bankowej następuje rozbudowywanie struktur organizacyjnych i wieloetapowych procesów decyzyjnych. Część banków będzie jednocześnie bezpośrednio bądź pośrednio podlegać pod nadzór kilku instytucji (jednolitego nadzoru, nadzoru makro- i mikroekonomicznego, nadzoru krajowego). Skład organów decyzyjnych jest rozbudowany liczebnie w celu uwzględnienia reprezentacji różnych organów unijnych i krajów członkowskich. Znamienne jest, że europejskie urzędy nadzoru nad poszczególnymi segmentami rynku finansowego mają swoje siedziby w stolicach trzech krajów unijnych. Taka organizacja nadzoru bardziej odzwierciedla dążenie do pilnowania narodowych interesów niż poszukiwanie racjonalnych zasad działania. W przypadku wystąpienia niespodziewanych zaburzeń na rynkach finansowych i konieczności szybkiego podejmowania decyzji rozwiązania te mogą okazać się mało skuteczne.

Należy również uwzględnić, że banki centralne mają największe doświadczenie w prowadzeniu polityki stabilizacyjnej i wzmocnienie ich roli w sprawowaniu nadzoru makroostrożnościowego oraz koordynowaniu zarządzania kryzysowego jest zasadne [Sławiński, 2014, s. 53]. Tymczasem ulokowanie nadzoru mikroostrożnościowego w ECB zostało spowodowane względami prawnymi, a nie ekonomicznymi, gdyż traktat z Maastricht nie dawał podstaw do utworzenia samodzielnego organu nadzoru unijnego. Realizacja przez tę samą instytucję polityki pieniężnej i nadzorczej powoduje zagrożenie konfliktem interesów. Prowadzenie polityki niskich stóp procentowych w okresie przed kryzysem zostało w poszczególnych krajach strefy euro wykorzystane w różny sposób. W Irlandii i Hiszpanii doprowadziło do powstania baniek spekulacyjnych na rynkach nieruchomości, w Portugalii zniechęciło do reform strukturalnych, w tym na rynku pracy, w Grecji posłużyło do finansowania nadmiernej konsumpcji. Czy w nowej sytuacji Rada Prezesów EBC, będąca ostatnią instancją decyzyjną zarówno w sprawach polityki pieniężnej, jak i nadzoru nad bankami, będzie w stanie pogodzić sprzeczności zadań w tym zakresie?

SRM będzie przez wiele lat oparty na środkach wnoszonych przez poszczególne kraje i przeznaczonych na ewentualne wspieranie banków mających w nich siedzibę. Środki te będą stanowiły w pełni wspólną pulę dopiero od 2024 r. Banki będą miały 
również bezpośredni dostęp do pomocy ze środków ESM. Zlikwidowanie pośrednictwa budżetów krajowych w tym zakresie odciąży budżety państw zaangażowanych wcześniej w ratowanie krajowych banków [Smaga, 2014, s. 492]. Banki będą tym samym miały przez dłuższy czas różny poziom bezpieczeństwa i różne możliwości pozyskiwania funduszy. W krajach $\mathrm{z}$ większymi problemami finansowymi będą musiały w związku z tym, tylko ze względu na swoją lokalizację, płacić wyższą marżę za ryzyko. W wyniku tego oprocentowanie kredytów będzie przez dłuższy czas zróżnicowane. Przełoży się to na dostępność kredytów i rozwój gospodarczy w poszczególnych krajach i regionach Europy. Różne poziomy gwarancji bezpieczeństwa banków ze strony państwa oraz niedokończony proces czyszczenia bilansów banków zakłóca kanały transmisji polityki pieniężnej [Merler, Wolff, 2013, s. 6]. W takich warunkach polityka pieniężna Europejskiego Banku Centralnego, a także polityki pieniężne banków centralnych nienależących do strefy euro będą napotykały na różne utrudnienia.

W polskim sektorze bankowym niemal połowa aktywów należy do grup finansowych z krajów Unii Europejskiej [Sytuacja, 2012, s. 8], ale banki z dominującym kapitałem zagranicznym funkcjonują jako spółki prawa krajowego. Oznacza to, że jednolity nadzór bankowy ma na nie co najwyżej wpływ pośredni, a w przypadku uporządkowanej likwidacji spółki matki ich deponenci nie byliby obciążani kosztami tego postępowania. Polska, jako kraj pozostający poza strefą euro, nie jest zobowiązana do przystąpienia do unii bankowej i na razie nie złożyła deklaracji o przystąpieniu do niej. Jednak na etapie opracowywania zasad jej funkcjonowania słusznie włączyła się do prac koncepcyjnych, zabezpieczając w niezbędnym zakresie interesy krajowego sektora bankowego. Unia bankowa nie zapewnia jednak krajom spoza strefy euro równych praw z krajami, które do niej należą [Smaga, 2014, s. 496]. Dotyczy to w szczególności dostępu do wsparcia finansowego dla banków wymagających restrukturyzacji.

\section{Zakończenie}

Kryzys finansowy, który w dużym stopniu był wynikiem działalności kredytowej dużych banków i rozwijania przez nie inżynierii finansowej, zmusił władze publiczne do zmiany polityki wobec nich. Obecnie priorytetem władz publicznych jest utrzymanie równowagi między zapewnieniem warunków do finansowania realnej gospodarki a stabilizacją finansową. Dlatego zdecydowano się na osłabienie pozycji dużych banków i zaczęto rozbudowywać system nadzoru nad nimi. Ze względu na rozbieżności interesów narodowych niemożliwe było stworzenie wspólnego nadzoru nad wszystkimi bankami w 28 krajach członkowskich. Zamiast tego powołano do życia dużą liczbę nowych instytucji i wprowadzono wiele norm nadzorczych, co grozi przeregulowaniem rynku. System ten nie jest spójny, gdyż nie obejmuje w jednakowym stopniu wszystkich krajów i wszystkich banków. Poszczególne regulacje są bardziej wyrazem kompromisów niż optymalnych rozwiązań. Cały 
proces tworzenia nowego systemu bezpieczeństwa finansowego został rozciągnięty na wiele lat, ale już obecnie powstają wątpliwości, czy jest to właściwa droga do poszukiwania stabilności finansowej? W warunkach silnie rozbudowanych regulacji nadzorczych można mieć obawy, że banki będą się koncentrowały na zachowaniu formalnej zgodności postępowania z normami nadzorczymi, a nie dbały o doskonalenie procedur zarządzania ryzykiem.

\section{Bibliografia}

1. Arcand J.-L. et al. (2012), Too Much Finance?, „IMF Working Paper”, WP/12/161.

2. Banking Structures Report (2013), European Central Bank, November 2013.

3. Boegl M. (2013), Die neue Bankenaufsicht bei EZB, „Die Bank”, nr 9.

4. Boegl M. (2013), Nationale makroprudenzielle Aufsicht etabliert, „Die Bank”, nr 6.

5. Council Regulation (EU) No. 1024/2013 of 15 October 2013 conferring specific tasks on the European Central Bank concerning policies relating to the prudential supervision of credit institutions, L 287/63, 29 October 2013.

6. Directive 2013/36/EU of the European Parliament and of the Council of 26 June 2013 on access to the activity of credit institutions and the prudential supervision of credit institutions and investment firms, L 176/13, $27^{\text {th }}$ June 2013.

7. Directive 2014/49/EU of the European Parliament and of the Council of 16 April 2014 on deposit guarantee schemes, L 173/149, 12 June 2014.

8. Directive 2014/59/EU of the European Parliament and of the Council of 15 May 2014 establishing a framework for the recovery and resolution of credit institutions and investment firms, OJ L 173, 12 June 2014.

9. European Financial Stability and Integration Report 2012, European Commission, April 2013.

10. Global Financial Development Report 2013. Rethinking Role of the State in Finance (2012), The World Bank, Washington.

11. Goedeckemeyer K.H. (2014), Für die Bankenunion gut gerüstet, „Die Bank”, nr 5.

12. High-level Expert Group on reforming the structure of the EU banking sector (2012), Chaired by E. Liikanen, Final Report, Brussels, 2 October 2012.

13. Hryckiewicz A., Pawłowska M. (2014), Zmiany w sektorze finansowym oraz ich wplyw na system finansowy w krajach UE, „Ekonomista”, nr 4.

14. Jordan T. (2013), Banken immer noch too big to fail, ,Finanz und Wirtschaft”, nr 72.

15. Małecki W. (2014), Przemiany sektora bankowego i ich konsekwencje, „Ekonomista”, nr 4.

16. Meller F. (2013), Banken als Intermediäre im traditionellen Bankengeschäft-Bedrohung durch Basel III?, „Corporate Finance law”, No. 2.

17. Merler S., Wolff G.B. (2013), Ending uncertainty: recapitalisation under European Central Bank supervision, „Breugel Policy Contribution”, 18 December 2013.

18. Mitręga-Niestrój K. (2011), Siatka bezpieczeństwa finansowego w Eurosystemie - stan obecny i perspektywy, [w:] J. Żabińska (red.), Rynki finansowe w Unii Europejskiej w strefie euro, CeDeWu, Warszawa.

19. Ortgies J. (2013), Auf der Zielgeraden, „Die Bank”, nr 2.

20. Sławiński A. (red.) (2011), Polityka pieniężna, Wyd. C.H. Beck, Warszawa.

21. Proposal of the European Parliament and of the Council on structural measures improving the resilience of EC credit institutions, 2014/0020/COD, 3 February 2014.

22. Regulation (EU) No 1093/2010 OF THE European Parliament and of the Council of 24 November 2010 establishing a European Supervisory Authority (European Banking Authority), L331/12, 15 December 2010. 
23. Regulation (EU) No 575/2013 of the European Parliament and of the Council of 26 June 2013 on prudential requirements for credit institutions and investment firms, L 176/13, 27 June 2013.

24. Regulation (EU) No 806/2014 of the European Parliament and of the Council of 15 July 2014 establishing uniform rules and a uniform procedure for the resolution of credit institutions and certain investment firms in the framework of a Single Resolution Mechanism and a Single Resolution Fund, L 225, 30 July 2014.

25. Rozwój systemu finansowego w Polsce w 2012 r. (2014), Narodowy Bank Polski, Warszawa.

26. Röseler R. (2014), Bankenaufsicht im Wandel, „Die Bank”, nr 4.

27. Smaga P. (2014), Optymalny ksztalt pierwszego filara unii bankowej, „Ekonomista”, nr 4.

28. Sytuacja polskiego sektora bankowego (2012), Komisja Nadzoru Finansowego, Warszawa, listopad 2012.

29. Top 1000 World Banks Ranking (2013), „The Banker”, 1 July 2013.

30. Zaleska M. (red.), Unia bankowa, Difin S.A., Warszawa 2013.

31. Völz M., Vedow M. (2011), Market discipline and too-big-to-fail in the CDS market: Does banks' size reduce market discipline?, „Journal of Empirical Finance”, Vol. 18.

32. Żabińska J. (2014), Unia bankowa, [w:] J. Pietrucha, J. Żabińska (red.), Zarządzanie gospodarcze w strefie euro, Difin S.A., Warszawa.

\section{The Banking Union as a component of financial security net}

Financial and economic crisis has led to a re-evaluation of the idea of financial markets deregulation. Public authorities have lost the control over the functioning of the large banks, whose activity put the stability and security of economies to threat. New supervising institutions are being created in the European Union. Their control covers all bodies from the Eurozone countries recognised as essential in terms of financial security system. Such supervision over remaining bodies from the EU is optional. With the conflict of national interests a complicated structure of entities and supervisory procedures has been created. This, in turn, may affect efficiency of tasks realised. One positive element of this change is implementing solutions, which will allow to brake rescuing big banks by means of public resources under crisis circumstances. 